\title{
Kadar Gula Darah Pengguna Kontrasepsi Hormonal
}

\author{
Siti Rahma, Andi Mursyidah, Yuli Yanti Rauf \\ Fakultas Olahraga dan Kesehatan Universitas Negeri Gorontalo \\ Email : rahmasyam82@gmail.com
}

\begin{abstract}
Abstrak
Kontrasepsi hormonal merupakan kontrasepsi yang mengandung hormon estrogen dan progesteron. Hormon tersebut diketahui dapat mempengaruhi kadar glukosa darah. Provinsi Gorontalo pada tahun 2017 dengan pengguna kontrasepsi hormonal pil sebanyak $22.64 \%$, suntik $37.36 \%$, implant $24.62 \%$. Tujuan penelitian ini adalah untuk mengetahui hubungan penggunaan kontrasepsi hormonal dengan kadar glukosa darah. Penelitian ini menggunakan observasional analitik dengan desain Cross sectional dengan teknik pengambilan sampel menggunakan purposive sampling, dengan jumlah Sampel sebanyak 132 responden. Hasil Penelitian menunjukan bahwa berdasarkan uji Chi Square tidak ada hubungan penggunaan kontrasepsi pil dengan kadar glukosa darah $\mathrm{p}=1,000(\alpha>0,05)$, ada hubungan penggunaan kontrasepsi suntik dengan kadar glukosa darah $p=0,025(\alpha<0,05)$, tidak ada hubungan penggunaan kontrasepsi implant dengan kadar glukosa darah $p=1,000(\alpha>0,05)$. Kesimpulan penelitian ini terdapat hubungan yang signifikan antara penggunaan kontrasepsi hormonal dengan kadar glukosa darah di puskesmas kota tengah kota gorontalo. Saran Perlu dilakukan penelitian lebih lanjut dengan mengendalikan variabel perancu yang ikut mempengaruhi seperti gaya hidup, pola makan dan keturunan.
\end{abstract}

Kata kunci: Kadar Glukosa Darah, Kontrasepsi Hormonal, Kontrasepsi

\begin{abstract}
Hormonal contraception is a contraceptive containing estrogen and progesterone hormones. The hormone affects blood glucose levels. The user of the hormonal contraceptive pill in Gorontalo in the year of 2017 as many as $22.64 \%, 37.36 \%$ injection, and implant $24.62 \%$. The purpose of the study was to determine relation of hormonal contraception user with blood glucose. This research employed an analytic observational with cross-sectional design by using purposive sampling technique which involved 132 respondents from 196 population. The result of research shows that there is no relation between pill contraceptive users with blood glucose level $p=1.000(\alpha>$ $0.05)$, relation of contraceptive injection user with blood glucose level $p=0.025(\alpha<0.05)$ no relation of implant contraceptive user with blood glucose level $p=1.000(\alpha>0.05)$ based on Chi-Square test. Thus, it is concluded that there is a significant relationship between users of hormonal contraceptives with blood glucose levels in the Public Health Centers in Kota Tengah Gorontalo City. In the future, it is suggested to do further research by controlling confounding variables influencing lifestyle, diet, and descendant.
\end{abstract}

Keywords: Blood Glucose Level, Contraception ,Hormonal Contraception

\section{PENDAHULUAN}

Kontrasepsi merupakan upaya untuk mencegah terjadinya kehamilan yang dapat bersifat sementara, dapat pula bersifat permanen yang terbagi atas dua yaitu hormonal dan non hormonal. Kontrasepsi hormonal terbagi atas 3 jenis yaitu pil, suntik, dan susuk (Purwaningsih \& Fatmawati, 2010). Fenomena dimasyarakat saat ini banyak wanita usia subur yang memilih menggunakan kontrasepsi hormonal. Kontrasepsi hormonal dipilih karena lebih praktis, efektif dan tidak perlu khawatir ada benda yang dipasang didalam tubuh seperti spiral (Setyarini, 2015).

Di Indonesia pada tahun 2017 dengan pengguna kontrasepsi hormonal implant $11.20 \%$, suntik $47.96 \%$, dan pil sebanyak $22.81 \%$. Dan diprovinsi Gorontalo pada tahun 2017 dengan pengguna kontrasepsi hormonal pil sebanyak $22.64 \%$, suntik $37.36 \%$, implant $24.62 \%$ (BKKBN, 2017). Kota Gorontalo pada tahun 2017 pengguna kontrasepsi hormonal pil sebanyak (28.1\%), suntik (58\%) dan implant (10.1\%). Menurut data yang diperoleh di Puskesmas kota 
tengah pada tahun 2017 peserta kontrasepsi hormonal suntik sebanyak 139 orang, implant 44 orang, dan pil 10 orang. Sedangkan tahun 2018 pada bulan Januari peserta kontra sespi hormonal suntik sebanyak 4 orang, implant 6 orang, dan belum terdapat peserta pil. Kontrasepsi hormonal yang mencakup pil, suntik, dan implant mengandung hormon estrogen dan progesteron. Dimana pil mini mengandung progesteron, pil kombinasi mengandung estrogen dan progesteron, pada suntik 1 bulan mengandung hormon estrogen dan progesteron, pada suntik 3 bulan mengandung hormon progesteron yang biasa tersedia dalam

Depomedroksiprogesteron dan Noretindron Enantat, sedangkan untuk implant hanya mengandung hormon progesteron saja dimana implant 3 tahun berisi ketodesogestrel dan implant 5 tahun berisi levonorgestrel (Mulyani \& Rinawati, 2013).

Hal ini ditegaskan Nurahmani \& Kurniadi 2015. Dimana dikatakan bahwa penggunaan yang lama akan menimbulkan efek samping diantaranya meningkatnya berat badan, timbunan kolestrol, hipertensi dan bahkan diabetes. Dimana terjadi peningkatan jumlah hormon progesteron dan estrogen didalam tubuh. Efek samping yang ditimbulkan dari kontrasepsi hormonal, salah satunya adalah kelainan terhadap metabolisme glukosa dalam tubuh. Kelainan metabolisme glukosa ini timbul akibat penggunaan kontrasepsi hormonal dimana hormon yang dikandung dapat mempengaruhi kerja insulin dalam metabolisme gula sehingga dapat meningkatkan kadar glukosa darah (Nurpalah, S, \& Holis, 2017).

Hal ini juga didukung Nurrahmini yang mengatakan bahwa pemakaian kontrasepsi suntik kombinasi meningkatkan kadar glukosa darah dimana kontrasepsi ini mengandung hormon estrogen dan progesteron. Namun hormon yang paling berpengaruh adalah hormon estrogen dimana hormon tersebut menghasilkan kadar glukosa darah dan menekan (supresi) respon insulin terhadap peningkatan tersebut, sehingga kerja kontrasepsi suntik berlawanan dengan kerja insulin. Perlawanan kerja insulin menyebabkan kerja pankreas semakin berat untuk memproduksi insulin. Semakin lama, pankreas menjadi tidak berfungsi secara optimal dan berdampak pada peningkatan kadar glukosa darah (Rahayu, Sundari, \& Widiyani, 2015). Peningkatan kadar glukosa darah yang disebabkan karena penggunaan kontrasepsi hormonal ini terjadi akibat perubahan berat badan, dimana hormon yang terkandung didalamnya mempermudah perubahan karbohidrat dan gula menjadi lemak, Sehingga lemak banyak yang tertumpuk di bawah kulit. Selain itu juga dapat merangsang pusat pengendali nafsu makan yang di hipotalamus yang dapat menyebabkan akseptor makan lebih banyak dari biasanya dan menurunkan aktifitas fisik akibatnya dapat menyebabkan berat badan bertambah (Rahayu, Sundari, \& Widiyani, 2015).

Di Gorontalo penyakit diabetes melitus merupakan salah satu penyakit yang banyak dijumpai. Berdasarkan data yang di peroleh dari dinas kesehatan provinsi berdasarkan Riset Kesehatan Dasar 2013 penderita diabetes melitus berdasarkan wawancara yang terdiagnosis dokter sebesar $1.5 \%$ dan diabetes melitus terdiagnosis dokter dan gejala sebesar $2.8 \%$. Prevalensi diabetes tertinggi terdapat di Kota Gorontalo sebesar 2.4\% (Riskesdas, 2013). 
Pada hasil wawancara dari 5 akseptor kontrasepsi hormonal, 1 orang menderita diabetes setelah menggunakan kontrasepsi hormonal suntik 3 bulan dengan pemakaian selama 3 tahun dengan berat badan $61 \mathrm{~kg}$ dan 4 orang lainya mengatakan tidak mengetahui kadar gula darahnya dan tidak pernah memeriksakan gula darah atau cekup kesehatan, setelah dilakukan pemeriksaan kadar gula darah didapatkan bahwa hasil kadar gula darah normal. Meskipun dari 5 orang hanya 1 kejadian diabetes hal ini masih tetap menjadi perhatian untuk masalah kesehatan atau menjadi bahan referensi.
Sehingga penulis memiliki ketertarikan untuk melakukan penelitian tentang tertarik mengambil judul Hubungan Penggunaan Kontrasepsi Hormonal Dengan Kadar Glukosa Darah di Puskesmas Kota Tengah Kota Gorontalo.

\section{METODE PENELITIAN}

Penelitian ini menggunakan desain Cross sectional dengan Jumlah Populasi sebanyak 196 dengan teknik pengambilan sampel menggunakan Purposive Sampling. Didapatkan jumlah sampel 132 responden. Penelitian ini menggunakan uji Chi square.

\section{HASIL PENELITIAN}

Berdasarkan hasil penelitian terhadap 132 responden adalah sebagai berikut:

Tabel 1. Distribusi Frekuensi Responden Berdasarkan Usia di Wilayah Kerja Puskesmas Kota Tengah Kota Gorontalo

\begin{tabular}{cccc}
\hline No. & Usia & $\mathbf{n}$ & $\mathbf{\%}$ \\
\hline 1. & $17-25$ tahun & 43 & 32,6 \\
\hline 2. & $26-35$ tahun & 58 & 43,9 \\
\hline 3. & $36-45$ tahun & 30 & 22,7 \\
\hline 4. & $46-55$ tahun & 1 & 8 \\
\hline & Total & $\mathbf{1 3 2}$ & $\mathbf{1 0 0}$ \\
\hline
\end{tabular}

Tabel 2. Distribusi Frekuensi Responden Berdasarkan lama penggunaan kontrasepsi di Wilayah Kerja Puskesmas Kota Tengah Kota Gorontalo

\begin{tabular}{cccc}
\hline No. & Lama Kontrasepsi & $\mathbf{n}$ & $\mathbf{\%}$ \\
\hline 1. & $1-5$ tahun & 76 & 57.6 \\
\hline 2. & $6-10$ tahun & 36 & 27.3 \\
\hline 3. & $11-15$ tahun & 14 & 10.6 \\
\hline 4. & $>15$ tahun & 6 & 4.5 \\
\hline & Total & $\mathbf{1 3 2}$ & $\mathbf{1 0 0}$ \\
\hline
\end{tabular}


Tabel 3. Distribusi Frekuensi Responden Berdasarkan Jenis Kontrasepsi di Wilayah Kerja Puskesmas Kota Tengah Kota Gorontalo

\begin{tabular}{cccc}
\hline No. & Jenis Kontrasepsi & $\mathbf{n}$ & $\mathbf{\%}$ \\
\hline 1. & Pil mini & 2 & 1.5 \\
\hline 2. & Pil kombinasi & 38 & 28.8 \\
\hline 3. & Suntik 1 bulan & 21 & 15.9 \\
\hline 4. & Suntik 3 bulan & 30 & 22.7 \\
\hline 5. & Implant 3 tahun & 38 & 28.8 \\
\hline .6. & Implant 5 tahun & 3 & 2.3 \\
\hline & Total & $\mathbf{1 3 2}$ & $\mathbf{1 0 0}$ \\
\hline
\end{tabular}

Tabel 4. Distribusi Frekuensi Responden Berdasarkan Kadar Glukosa Darah di Wilayah Kerja Puskesmas Kota Tengah Kota Gorontalo

\begin{tabular}{cccc}
\hline No. & Kadar Glukosa Darah & $\mathbf{n}$ & $\mathbf{\%}$ \\
\hline 1. & $<126 \mathrm{mg} / \mathrm{dl}$ & 116 & 87.9 \\
\hline 2. & $\geq 126 \mathrm{mg} / \mathrm{dl}$ & 16 & 12.1 \\
\hline & Total & $\mathbf{1 3 2}$ & $\mathbf{1 0 0}$ \\
\hline
\end{tabular}

\section{Analisa Bivariat}

Tabel 5. Hubungan Kontrasepsi Pil dengan Kadar Glukosa Darah di Wilayah Kerja Puskesmas Kota Tengah Kota Gorontalo.

\begin{tabular}{|c|c|c|c|c|c|c|c|}
\hline \multirow{3}{*}{$\begin{array}{c}\text { Jenis } \\
\text { kontrasepsi }\end{array}$} & \multicolumn{4}{|c|}{ Glukosa Darah } & & & \multirow{3}{*}{ P-Value } \\
\hline & \multicolumn{2}{|c|}{$<126 \mathrm{mg} / \mathrm{dl}$} & \multicolumn{2}{|c|}{$\geq 126 \mathrm{mg} / \mathrm{dl}$} & \multicolumn{2}{|c|}{ Jumlah } & \\
\hline & $\mathrm{N}$ & $\%$ & $\mathrm{~N}$ & $\%$ & $\mathrm{~N}$ & $\%$ & \\
\hline Pil mini & 2 & 100 & 0 & 0 & 2 & 100 & \\
\hline Pil kombinasi & 34 & 89,5 & 4 & 10,5 & 38 & 100 & 1,000 \\
\hline Jumlah & 36 & 90,0 & 4 & 10,5 & 40 & & \\
\hline
\end{tabular}

Tabel 6. Hubungan Penggunaan Kontrasepsi Suntik dengan Kadar Glukosa Darah

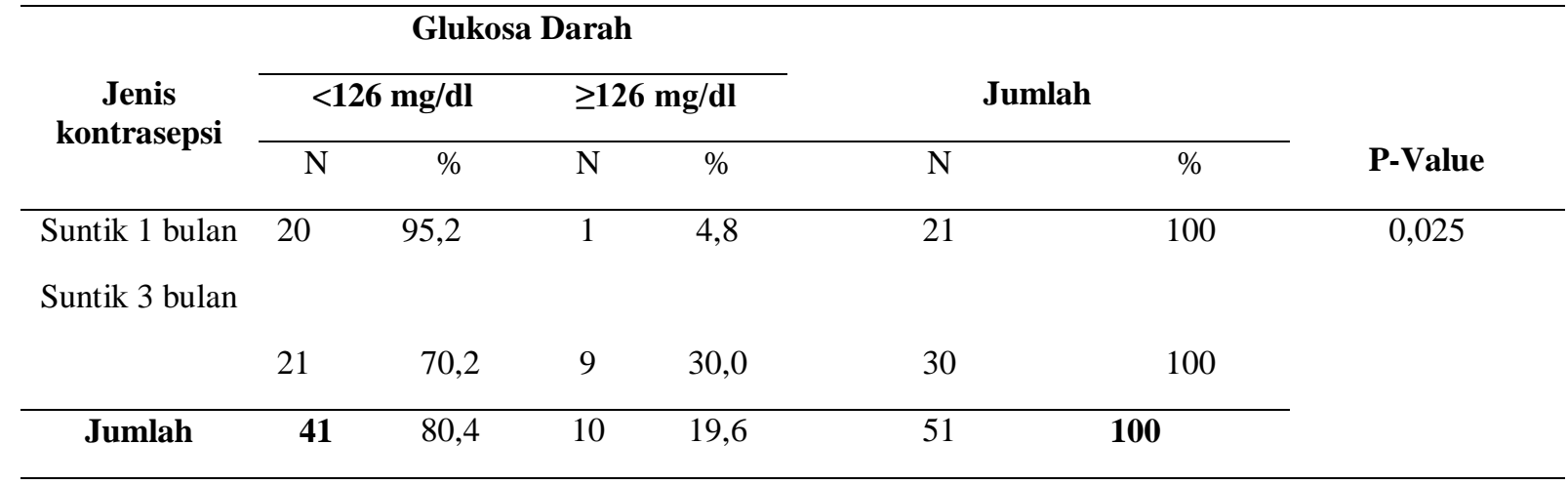


Tabel 7. Hubungan Penggunaan Kontrasepsi Implant dengan Kadar Glukosa Darah

\begin{tabular}{|c|c|c|c|c|c|c|c|}
\hline \multirow{3}{*}{$\begin{array}{c}\text { Jenis } \\
\text { kontrasepsi }\end{array}$} & \multicolumn{4}{|c|}{ Glukosa Darah } & & & \multirow{3}{*}{ P-Value } \\
\hline & \multicolumn{2}{|c|}{$<126 \mathrm{mg} / \mathrm{dl}$} & \multicolumn{2}{|c|}{$\geq 126 \mathrm{mg} / \mathrm{dl}$} & \multicolumn{2}{|c|}{ Jumlah } & \\
\hline & $\mathrm{N}$ & $\%$ & $\mathrm{~N}$ & $\%$ & $\mathrm{~N}$ & $\%$ & \\
\hline $\begin{array}{c}\text { Implant } 3 \\
\text { tahun }\end{array}$ & 36 & 94,7 & 2 & 5,3 & 38 & 100 & 1,000 \\
\hline $\begin{array}{c}\text { Implant } 5 \\
\text { tahun }\end{array}$ & 3 & 100 & 0 & 0 & 3 & 100 & \\
\hline Jumlah & 39 & 95,1 & 2 & 4,9 & 41 & 100 & \\
\hline
\end{tabular}

\section{PEMBAHASAN}

\section{Penggunaan kontrasepsi hormonal}

Berdasarkan tabel 4 diatas menunjukan bahwa dari 132 responden, berdasarkan jenis kontrasepsi kategori tertinggi pada kontrasepsi pil kombinasi sebanyak 38 responden $(28,8 \%)$ dan Implant 3 tahun dengan frekuensi sebanyak 38 responden $(28,8 \%)$ dan terendah pada kontrasepsi Pil Mini sebanyak 2 responden (1,5\%).

Kontrasepsi hormonal yang paling banyak digunakan yaitu pil kombinasi sebanyak 38 responden dan implant 3 tahun sebanyak 38 responden dibandingkan kontrasepsi yang lain yaitu pil mini 2 responden, suntik 1 bulan 21 responden, suntik 3 bulan 30 responden, dan implant 5 tahun 3 responden. Hal ini terjadi karena berdasarkan hasil penelitian pengguna implant rata-rata usia kurang dari 40 tahun dan berdasarkan wawancara mereka memilih menggunakan kontrasepsi implant tersebut karena cocok, simple, nyaman dan praktis.

Hal ini sesuai penelitian Sakinah (2012) yang menunjukan bahwa kontrasepsi implant yang paling banyak digunakan untuk mencegah / menunda kehamilanya karena dianggap efektif, praktis dan tidak berhubungan dengan daerah yang sensitif. Dibandingkan kontrasepsi yang lain seperti pil dan suntik yang untuk pengguna pil harus diminum setiap hari pada waktu yang sama dan jangan sampai ada yang terlewatkan dan untuk suntik mereka merasa tidak cocok.

Untuk pengguna pil dengan rata-rata usia kurang dari 40 tahun dan berdasarkan wawancara mereka memilih menggunakan kontrasepsi tersebut karena cocok, tidak perlu ada benda yang dipasang dalam tubuh, biaya murah dan dapat dihentikan setiap saat bila ingin hamil lagi. Hal ini sesuai dengan teori Saifuddin (2006), yang menjelaskan bahwa pil merupakan kontrasepsi yang digunakan dengan cara diminum setiap hari jadi sama sekali tidak dapat mengganggu hubungan seksual, mudah dihentikan setiap saat karena kesuburan segera kembali setelah pil dihentikan. Selain itu pada kelompok umur 20-35 tahun pil juga digunakan sebagai kontrasepsi jangka panjang selama perempuan masih ingin menggunakannya.

Kemudian pengguna suntik berdasarkan wawancara bahwa mereka memilih menggunakan kontrasepsi ini karena lebih efektif dalam menunda kehamilan, aman dan harga terjangkau dibandingkan kontrasepsi yang lain seperti pil dan implant. 
Hal ini sesuai dengan teori yang dikemukakan oleh Affandi (2013), bahwa penggunaan kontrasepsi suntik sangat efektif, aman, dan dapat dipakai oleh semua perempuan dalam usia reproduksi.

Adapun Menurut Handayani (2010), pemilihan alat kontrasepsi merupakan faktor yang penting dalam kehidupan seorang wanita, dengan tingkatan kebutuhan yang bervariasi sesuai dengan tahapan dalam rangkaian kehidupan tertentu, dan sebaiknya dipandang dalam konteks seksual dan kesehatan reproduksi yang lebih luas.

\section{Kadar glukosa darah pengguna kontrasepsi hormonal}

Berdasarkan tabel 5 diatas menunjukan bahwa dari 132 responden, berdasarkan glukosa darah kategori tertinggi pada glukosa darah $<126 \mathrm{mg} / \mathrm{dl}$ dengan frekuensi sebanyak 116 responden $(87.9 \%)$ dan terendah glukosa darah $\geq 126 \mathrm{mg} / \mathrm{dl}$ sebanyak 16 responden (12.1\%). Pengguna kontrasepsi hormonal, didapatkan paling banyak kadar glukosa darah dalam keadaan normal $<126 \mathrm{mg} / \mathrm{dl}$ sebanyak 116 responden $(87,9 \%)$, karena rata-rata responden berada pada usia 26-35 tahun dan berdasarkan wawancara mereka tidak memiliki riwayat penyakit, dan dalam umur tersebut fisiologis tubuh dan peredaran darah masih bagus, sehingga untuk mengalami gangguan metabolik seperti penyakit hiperglikemi atau diabetes mellitus masih kurang pada umur tersebut, hal ini sesuai teori Merck (2008), bahwa umumnya manusia mengalami penurunan fisiologis yang secara dramatis menurun dengan cepat pada usia setelah 40 tahun dan beresiko pada penurunan fungsi endokrin pankreas yang memproduksi insulin, sehingga hampir semua kadar glukosa darah dalam penelitian ini dalam keadaan normal. Kemudian terdapat 16 responden $(12,1 \%)$ yang mengalami kenaikan kadar glukosa darah $\geq 126 \mathrm{mg} / \mathrm{dl}$, hal ini disebabkan karena penggunaan kontrasepsi yang lama diatas 10 tahun dan responden berada pada umur diatas 35 tahun, sehingga hal ini yang menyebabkan kenaikan kadar glukosa darah.

Hal ini sesuai dengan teori Nurrahmini (2012), penggunaan kontrasepsi dalam jangka waktu yang lama dapat mengakibatkan gangguan pankreas. Perlawanan kerja insulin menyebabkan kerja pankreas semakin berat untuk memproduksi insulin. Semakin lama, pankreas menjadi tidak berfungsi secara optimal dan berdampak pada peningkatan glukosa darah. Selain itu penurunan produksi insulin mengakibatkan berkurangnya jumlah glukosa yang masuk ke dalam sel, sehingga glukosa akan tetap berada dalam pembuluh darah dan menyebabkan kadar glukosa darah meningkat.

Hal ini juga sesuai dengan teori yang dikemukakan oleh Handayani dan Yulaikah, (2017). Kontrasepsi hormonal adalah kontrasepsi yang mengandung hormon steroid yaitu hormon estrogen dan progesteron. Hormon yang terkandung dalam kontrasepsi hormonal adalah hormon progesteron saja atau kombinasi antara estrogen dan progesteron. Kontrasepsi hormonal yang beredar saat ini dapat berupa pil, suntik atau implant.

Pemakaian kontrasepsi hormonal yang mengandung hormon estrogen dan progesteron dapat menimbulkan efek samping, salah satunya adalah kelainan terhadap metabolisme glukosa dalam tubuh. Kelainan metabolisme glukosa ini timbul akibat penggunaan kontrasepsi hormonal dimana hormon estrogen dan progesteron yang dikandung dapat mempengaruhi kerja 
insulin dalam metabolisme gula sehingga dapat meningkatkan kadar glukosa darah (Notodiharjo, 2012).

Kadar glukosa darah juga dipengaruhi oleh beberapa faktor salah satunya adalah umur. Pada masa usia 20-35 tahun yaitu usia terbaik untuk hamil dan melahirkan serta pada usia tersebut juga diperlukan jenis kontrasepsi yang mempunyai efektivitas cukup tinggi dan reversibilitas cukup tinggi karena pada usia tersebut juga merupakan usia yang masih reproduktif sehingga masih rentan dalam menggunakan dan memilih alat kontrasepsi hormonal yang juga mempengaruhi kadar gula darah (Ekawati, 2010). Selain faktor umur yang menjadi salah satu peningkatan kadar glukosa darah, pekerjaan juga menjadi salah satu yang berkaitan erat dengan peningkatan kadar glukosa darah sebab pekerjaan juga merupakan salah satu faktor yang dapat mempengaruhi kadar glukosa darah. Hal ini sesuai dengan teori yang dikemukakan oleh Barnes (2011). Pekerjaan mempunyai hubungan yang sangat erat dengan aktifitas fisik yang dilakukan individu. Aktifitas fisik berhubungan dengan peningkatan kecepatan pemulihan glukosa otot (seberapa banyak otot mengambil glukosa dari aliran darah). Saat beraktifitas otot menggunakan glukosa yang tersimpan dan jika glukosa berkurang otot mengisi kekosongan dengan mengambil glukosa dari darah, hal ini kan mengakibatkan menurunya glukosa darah, sehingga memperbesar pengendalian glukosa darah.

\section{Hubungan penggunaan kontrasepsi hormonal pil dengan kadar glukosa darah}

Berdasarkan tabel 6 diatas menunjukan bahwa dari 40 responden yang menggunakan kontrasepsi jenis pil, yang terdiri dari 2 responden pil mini yang kadar glukosa darah <126 mg/dl (normal) dan penggunaan pil kombinasi terdapat 34 responden dengan kadar glukosa darah $<126$ $\mathrm{mg} / \mathrm{dl}$ dan terdapat 4 responden dengan kadar glukosa darah $\geq 126 \quad \mathrm{mg} / \mathrm{dl}$ (hiperglikemi).

Setelah dilakukan uji chi-square didapatkan hasil $\mathrm{p}$-value 1,000 dimana lebih besar dari $\alpha(0,05)$, sehingga tidak terdapat hubungan yang singnifikan antara penggunaan kontrasepsi hormonal pil dengan kadar glukosa darah diPuskesmas Kota Tengah Kota Gorontalo. Dimana pada penelitian ini didapatkan bahwa rata-rata memiliki kadar glukosa darah normal pada pil mini 2 reponden dan pil kombinasi 34 responden. Hal ini disebabkan karena pada pil mini penggunaannya kurang dari 3 tahun dan pada pil kombinasi penggunaanya kurang dari 15 tahun, dimana pil kombinasi mengandung hormon estogen dan progesteron, dimana kerja estrogen dan progesteron dalam hal kadar glukosa darah itu berlawanan, yang mana progesteron yang menaikan kadar glukosa darah tetapi estrogen yang menstabilkan. Sedangkan pada pil mini hanya mengandung estrogen saja, dimana sesuai teori yang dikemukakan oleh Nurpalah (2017) bahwa kontrasepsi oral yang hanya mengandung estrogen saja tidak memiliki efek merugikan pada metabolisme glukosa, tetapi yang mengandung progesteron menunjukan antagonisme dengan insulin.

Pada penelitian ini didapatkan yang menggunakan pil kombinasi mengalami kenaikan kadar glukosa darah sebanyak 4 responden, dimana ke 4 responden tersebut berumur diatas 40 tahun, dengan lama penggunaan diatas 15 tahun. Hal ini menunjukan bahwa usia dan lama penggunaan kontrasepsi hormonal berpengaruh terhadap kadar glukosa darah. 
Resiko diabetes mellitus akan meningkat sejalan bertambahnya usia, terutama setelah usia 40 tahun karena jumlah sel-sel beta di dalam pankreas yang memproduksi insulin menurun seiring bertambahnya umur (Ramaimah, 2013).

Hal ini sesuai dengan penelitian yang dilakukan oleh Isa Irawati (2014) yang meneliti tentang "Kadar Glukosa Darah pada Akseptor Pil Kb Kombinasi dipolindes Anyelir Jetis Mojokerto" dari hasil penelitiannya menunjukkan bahwa sebagian besar responden mempunyai kadar gula darah normal pada akseptor kontrasepsi pil kombinasi di Polindes Anyerli Mojokerto sebanyak 14 responden $(42,4 \%)$. Sehingga dapat disimpulkan bahwa tidak ada hubungan penggunaan kontrasepsi hormonal pil dengan kadar glukosa di Polindes Anyerli Mojokerto.

Penelitian diatas juga sesuai dengan teori yang dikemukakan oleh Rianti Nurpalah (2017), Kontrasepsi oral yang hanya mengandung estrogen saja, tidak memiliki efek merugikan pada metabolisme glukosa, tetapi yang mengandung progesteron menunjukkan antagonisme dengan insulin.

\section{Hubungan penggunaan kontrasepsi hormonal suntik dengan kadar glukosa darah}

Berdasarkan tabel 7 menunjukan bahwa dari 51 responden yang menggunakan kontrasepsi jenis suntik, yang terdiri dari 20 responden suntik 1 bulan dengan kadar glukosa darah $<126 \mathrm{mg} / \mathrm{dl}$ (normal) dan 1 responden dengan kadar glukosa darah $\geq 126$ $\mathrm{mg} / \mathrm{dl}$ (hiperglikemi), dan pengguna suntik 3 bulan terdapat 21 responden dengan kadar glukosa darah <126 mg/dl (normal) dan terdapat 9 responden yang dengan kadar glukosa darah $\geq 126 \mathrm{mg} / \mathrm{dl}$ (hiperglikemi).
Setelah dilakukan uji chi-square didapatkan hasil p-value 0,025 dimana lebih kecil dari $\alpha(0,05)$, sehingga terdapat hubungan yang singnifikan antara penggunaan kontrasepsi hormonal suntik dengan kadar glukosa darah diPuskesmas Kota Tengah Kota Gorontalo. Dimana pada penelitian ini didapatkan bahwa yang menggunakan suntik 1 bulan mengalami kenaikan kadar glukosa darah sebanyak 1 responden, dan suntik 3 bulan sebanyak 9 reponden yang mengalami kenaikan kadar glukosa darah, hal ini karena rata-rata responden tersebut berumur diatas 40 tahun dengan lama penggunaan diatas 15 tahun. Hal ini sesuai teori yang menjelaskan bahwa usia dan lama pemakaian kontrasepsi hormonal juga berkaitan erat dengan kenaikan kadar glukosa darah, sebab semakin lama pemakaian kontrasepsi hormonal dapat menyebabkan gangguan hormon dalam tubuh.

Pada penelitian ini juga didapatkan ratarata memiliki kadar glukosa darah normal pada pengguna kontrasepsi hormonal suntik 1 bulan sebanyak 20 responden dan 21 responden pada suntik 3 bulan, hal ini karena rata-rata penggunaanya kurang dari 10 tahun. Hal ini sejalan dengan penelitian Sri Rahayu (2015) yang mengatakan bahwa penggunaan kontrasepsi kurang dari 10 tahun tidak memiliki hubungan yang signifikan dengan kadar glukosa darah. Hal ini menunjukan bahwa usia dan lama penggunaan kontrasepsi hormonal berpengaruh terhadap kadar glukosa darah. Kontrasepsi suntik 1 bulan ini dimana seperti diketahui bahwa pada kontrasepsi tersebut mengandung estrogen dan progesteron yang cara kerjanya berlawanan dengan kerja insulin, sehingga pada kontrasepsi suntik 1 bulan hanya 1 yang mengalami kenaikan kadar glukosa darah 
dan yang lainnya normal. Sedangkan pada suntik 3 bulan yang mengalami kenaikan kadar glukosa darah sebanyak 9 responden, hal ini disebabkan karena kontrasepsi tersebut mengandung progesteron dimana progesteron memiliki sifat anti-insulin serta dapat menjadikan sel-sel kurang sensitiv terhadap insulin yang menyebabkan terjadinya resistensi insulin dalam tubuh dan juga pada kontrasepsi ini kandungan hormon progesteron terlalu tinggi yaitu 150 mg.

Hal ini sesuai teori yang menjelaskan bahwa kontrasepsi hormonal suntik mengandung hormon steroid dengan anti insulin rendah, bahkan penggunaan dalam jangka waktu yang lama dapat mengakibatkan gangguan pankreas dan usia juga berpengaruh terhadap kadar glukosa darah. Resiko diabetes mellitus akan meningkat sejalan bertambahnya usia, terutama setelah usia 40 tahun karena jumlah sel-sel beta di dalam pankreas yang memproduksi insulin menurun seiring bertambahnya umur (Ramaimah, 2013).

Hal ini didukung oleh penelitian yang dilakukan Fatimah Sari, Mustika Pramestiyani (2015) Stikes Guna Bangsa Yogyakarta, yang meneliti tentang "Studi komparasi kadar glukosa darah sewaktu pada akseptor KB suntik kombinasi dan progestin di Bpm Yosi Trihana Kabupaten Klaten Jawa Tengah". Hasil penelitian menunjukan bahwa nilai $p$-value $=0,000$ sehingga $\alpha<0.05$ dapat dikatakan bahwa ada perbedaan antara kadar gula darah sewaktu pada akseptor KB suntik kombinasi dan progestin di Bpm Yosi trihana Kabupaten Klaten Jawa Tengah.

Berdasarkan hasil wawancara, sejak menggunakan kontrasepsi suntik responden merasa nafsu makannya bertambah, hal ini juga sesuai dengan teori yang dikemukakan oleh Hartanto (2010), mengemukakan bahwa penyebab peningkatan kadar glukosa darah disebabkan juga oleh berat badan, karena hormon progesteron mempermudah perubahan karbohidrat dan gula menjadi lemak, sehingga lemak dibawah kulit bertambah, dan hormon estrogen merangsang pusat pengendalian nafsu makan di hipotalamus, yang menyebabkan akseptor makan lebih banyak dari biasanya, dan penyebab peningkatan berat badan juga dapat dipengaruhi oleh beberapa faktor seperti faktor genetik, hormonal, sosial ekonomi, kurangnya aktivitas fisik, asupan nutrisi yang tidak terkontrol. Hasdianah (2014), mengemukakan bahwa kelebihan berat badan dapat memperbesar resiko munculnya penyakit degeneratif seperti diabetes, penyakit jantung, dan hipertensi.

\section{Hubungan penggunaan kontrasepsi hormonal implant dengan kadar glukosa darah}

Berdasarkan tabel 8 menunjukan bahwa dari 41 responden yang menggunakan kontrasepsi Implant, yang terdiri dari 36 reponden implant 3 tahun dengan kadar glukosa darah <126 mg/dl (normal) dan terdapat 2 resonden dengan kadar glukosa darah $\geq 126 \mathrm{mg} / \mathrm{dl}$ (hiperglikemi), dan pengguna implant 5 tahun terdapat 3 responden dengan kadar glukosa darah $<126$ $\mathrm{mg} / \mathrm{dl}$ (normal).

Setelah dilakukan uji chi-square didapatkan hasil p-value 1,000 dimana lebih besar dari $\alpha(0,05)$, sehingga tidak terdapat hubungan yang singnifikan antara penggunaan kontrasepsi hormonal implant dengan kadar glukosa darah diPuskesmas Kota Tengah Kota Gorontalo. Dimana pada penelitian ini didapatkan bahwa rata-rata memiliki kadar glukosa darah normal pada implant 3 tahun sebanyak 36 responden dan 
3 responden pada implant 5 tahun, hal ini karena rata-rata usia kurang dari 40 tahun dengan lama penggunaan kurang dari 15 tahun, tetapi ada yang menggunakan implant 3 tahun namun mengalami kenaikan kadar glukosa darah sebanyak 2 responden, hal ini karena berdasarkan wawancara mereka mengatakan mengalami kenaikan berat badan selama menggunakan kontrasepsi tersebut dan juga implant 3 tahun mengandung $68 \mathrm{mg}$ ketonogestrel dan pada implant 5 tahun mengandung $36 \mathrm{mg}$ levonogestrel sehingga menyebabkan 2 responden tersebut mengalami kenaikan kadar glukosa darah

Hal ini sesuai penelitian Rahayu (2015), perubahan berat badan, dimana hormon yang terkandung didalamnya mempermudah perubahan karbohidrat dan gula menjadi lemak, Sehingga lemak banyak yang tertumpuk di bawah kulit. Selain itu juga dapat merangsang pusat pengendali nafsu makan yang di hipotalamus yang dapat menyebabkan akseptor makan lebih banyak dari biasanya dan menurunkan aktifitas fisik akibatnya dapat menyebabkan berat badan bertambah. Pada kontrasepsi ini kandungan hormon progesteron tidak terlalu tinggi yaitu $36 \mathrm{mg}$. Hal ini juga disebabkan karena pada implant mengandung hormon progesteron, yang diketahui bahwa hormon tersebut dapat meningkatkan glukosa darah, tetapi pada penelitian ini rata-rata kadar glukosa darah normal. Sehingga pada penelitian ini tidak terdapat hubungan yang signifikan antara penggunaan kontrasepsi hormonal implant dengan kadar glukosa darah.

Teori ini sesuai yang dikemukakan oleh suherman (2011), bahwa pada pengguna kontrasepsi pil dan implant pemberian preparat yang mengandung devirat progestin dengan khasiat anabolik kuat dapat menambah nafsu makan dan dapat mengakibatkan kenaikan kadar glukosa darah.

Penelitian ini juga didukung oleh Mionoki (2014), Implant adalah alat kontrasepsi yang ditanamkan dibawah kulit. Implant ini mengandung hormon progesterone yang bekerja menghambat proses ovulasi di dalam kelenjar telur. Cara kerjanya lender serviks menjadi kental, menganggu proses pembentukan endometrium sehingga sulit terjadi implantasi, mengurangi transportasi sperma, menekan ovulasi.

\section{KESIMPULAN}

Dari hasil penelitian ini dapat disimpulkan bahwa tidak terdapat hubungan antara penggunaan kontrasepsi hormonal pil dengan kadar glukosa darah dan juga tidak terdapat hubungan penggunaan kontrasepsi hormonal implant dengan kadar glukosa darah di Puskesmas Kota Tengah Kota Gorontalo, akan tetapi terdapat hubungan antara kontrasepsi hormonal suntik dengan kadar glukosa darah.

\section{DAFTAR PUSTAKA}

Affandi, B. 2014. Buku Panduan Praktis Pelayanan Kontrasepi edisi 3. Jakarta: Bina Pustaka Sarwono Prawirohardjo.

American Diabetes Association. 2016. Executive Summary: Standar of Medical care In Diabetes.

Barnes, D. 2011. program olah raga diabetes . Yogyakarta: Citra Aji Paramana.

Badan Koordinasi Keluarga Berencana Nasional. 2012. KB Sebagai Suatu Kebutuhan.

Darmawati, \& Fitri. 2012. Hubungan Penggunaan Kontrasepsi Hormonal dengan Kenaikan Berat Badan pada Akseptor Kontrasepsi Hormonal di 
Desa Batoh tahun 2012 Jurnal Ilmu

Keperawatan, Vol.1 No.1 2.

Depkes RI. 2009. Data dan Informasi.Profil

Kesehatan Indonesia Kategori umur berdasarkan kematangan biologis.Jakarta.

Donsu, J. D. 2016. Metodologi Penelitian Keperawatan. Yogyakarta: PustakaBaruPress.

Ekawati, D. 2010. Pengaruh KB Suntik DMPA terhadap peningkatan berat badan di BPS Siti Syamsiah Wonokarto Wonogiri.

Fatimah Sari, M. P. 2017. Studi Komparasi Kadar Glukosa Darah Sewaktu akseptor KB suntik kombinasi dan progestin di Bpm Yosi Trihana Kabupaten Klaten Jawa Tengah. Jurnal Kesehatan "Samodra Ilmu" Vol. 08 No. 01, 1-5.

Fatimah, R. N. 2015. Diabetes Melitus Tipe 2. J Majority, 95-96.

Febrianto, B., Agustin, M., Rahardianingtyas, E., Anasiru, A., Tomayahu, M., Hiola, T., et al. 2013. Riset Kesehatan Dasar.Pokok - Pokok Hasil Riskesdas Provinsi Gorontalo. Jakarta: Lembaga Penerbitan Badan Penelitian dan Pengembanagan Kesehatan Kementrian Kesehatan RI.

Firdaus, M. 2017. Diabetes dan Rumput Laut Coklat. Malang: UB Press.

Fransisca, K. 2013. Awas Penyebab Pankreas Rusak Penyebab Diabetes. Jakarta: Cerdas Sehat.

Haryati, N., Fajarsari, D., \& Suryani, E. S. 2010. Pengaruh Lamanya Alat Kontrasepsi Depomedroxy Progesterone Acetat Terhadap Kenaikan Berat Badan di BPS Supriyatni Desa Paketingan Kecamatan Sampang

KabupatenCilacap,2.

Hasdiayana, \& Suprapto, S. I. 2014. Patologi \& Patofisiologi Penyakit. Yogyakarta: Nuha Medika.

Hasmi. 2016. Metode Penelitian Kesehatan. Jayapura: In Media.
Handayani. 2010. Buku Ajar Pelayanan Keluarga Berencana . Yogyakarta: Pustaka Rihana.

Hartanto, H.2010. Keluarga Berencana dan Kontrasepsi. Jakarta: Pustaka Sinar Harapan.

Hidayah, N., Purnomo, \& Fitriani, D. 2015. Obesitas dan Riwayat Genetik dengan Kejadian Diabetes Mellitus pada pengguna KB suntik Depogestin di BPMHandayani Isro' Desa Welahan Stikes Muhammadiyah Kudus. Jurnal Volume 6 No.3,36-45.

Irawati, I. 2014. Kadar Glukosa Darah Pada Akseptor PIL KB Kombinasi Di Polindes Anyelir Jetis. 1-6.

J.Corwin, E. 2009. Buku Saku Patofisiologis. Jakarta:EGC: Penerbit Buku Kedokteran.

Kementrian Kesehatan RI. 2017. Data dan Informasi.Profil Kesehatan Indonesia Presentase peserta KB Baru menurut Metode Kontrasepsi dan Provinsi. Jakarta.

Mulyani, N. S., \& Rinawati, M. 2013. Keluarga Berencana dan Alat Kontrasepsi. Yogyakarta: Nuha Medika.

Mionoki, d. A., dkk. 2014, 1 juni. Majalah

Kesehatan Muslim. Tetap Prima Saat Haid Tiba, p. 43.

Noor. 2008. pengantar epidemologi penyakit menular. Jakarata: Rinika cipta.

Nurrahmini, U. 2012. Stop Diabetes. Yogyakarta: Familia Group Releasi Inti Media.

Ndraha, S. 2014. Diabetes Melitus Tipe 2 Dan Tatalaksana Terkini. Departemen penyakit Dalam Fakultas Kedokteran Universitas Krida Wacana Jakarta.

Notodiharjo R. 2012 Reproduksi, Kontrasepsi dan Keluarga Berencana, kanisius; Yogyakarta

Notoatmodjo, S. 2012. Metodologi Penelitian Kesehatan. Jakarta: Rineka Cipta

Nurahmani, U., \& Kurniadi, H. 2015. STOP! Gejala Penyakit Jantung Koroner, Kolestrol Tinggi,Diabetes 
Melitus,Hipertensi. Yogyakarta: Istana Media.

Nurpalah, R., S, D. N., \& Holis, N. 2017. Pemeriksaan Glukosa Darah Pada Wanita Pengguna Kontrasepsi Oral Dan Pada Wanita Hamil Trimester III. Jurnal Kesehatan Bakti Tunas Husada, $1-5$.

PERKENI. 2015. Konsesus Pengelolaan dan Pencegahan Diabetes Melitus tipe 2 Di Indonesia. Pengurus Besar Perkumpulan Endokrinologi Indonesia (PB PERKENI).

Purwaningsih, W., \& Fatmawati, S. 2010. Asuhan Keperawatan Maternitas. Yogyakarta: Nuha Medika.

Radita, K. 2009. Faktor-Faktor yang Mempengaruhi Pemilihan Jenis Kontrasepsi yang digunakan pada Pasangan Usia Subur. KTI.Fakultas Kedokteran Universitas Ponegoro Semarang.

Rahayu, S., Sundari, S., \& Widiyani, E. 2015. Hubungan Lama Pemakaian Kontrasepsi Suntik Kombinasi Dengan Kadar Glukosa Darah DI BPM "E" Kecamatan Purwosari, Pasuruan. The Southeast Asian Journal of Midwifery Vol. 1, No.1, 10-15.

Rian Adi Pamungkas, S. A. 2017. Metodologi Riset Keperawatan. Jakarta Timur: CV.Trans Info Media.

Rianti Nurpalah, D. N. 2017. Pemeriksaan Glukosa Darah pada Wanita Pengguna Kontrasepsi oral dan pada Wanita Hamil Trimester III. Jurnal Kesehatan Bakti Tunas Husada.

Ramaimah, S. 2013. Diabetes : Cara Mengetahui Gejala Diabetes dan Mendeteksi Sejak Dini. Jakarta: PT. Bhuana Ilmu Populer

Saifuddin, Abdul Bari.2006. Buku Panduan Praktis Pelayanan Kontrasepsi Jakarta : Yayasan Bina Pustaka Sarwono Prawirohardjo

Sakinah.2012.Gambaran Penggunaan Kontrasepsi Implant pada Pasangan Usia Subur (PUS) Di Puskesmas Perawatan Lakessi Kota Parepare.
Setiadi. 2013. Konsep dan Praktek Penulisan Riset Keperawatan . Yogyakarta: Graha Ilmu.

Setyarini, D. I. 2015. Lama Penggunaan DMPA dan IMT Akseptor KB Suntik. Jurnal Informasi Kesehatan Indonesia, Volume 1, No.1, 8.

Siswosuharjo, S., \& Chakrawati, F. 2011. Panduan Super Lengkap Hamil Sehat. Depok: Penebar Plus.

Siyoto,S.,\& A.Sodik.2015. Dasar Metodologi Penelitian (Cet.1). Jakarta: Literasi Media Publising

Smeltzer, S. C. 2013. Buku Ajar Keperawatan Medikal Bedah. Jakarta: EGC.

Soegondo, S. 2009. Penatalaksanaan Diabetes Terpadu Sebagai Panduan Penatalaksanaan Diabetes Melitus Bagi Dokter maupun Edukator Diabetes. Jakarta: Fakultas Kedokteran Universitas Indonesia.

Sri Rahayu, S. S. 2015. Hubungan lama pemakaian kontrasepsi suntik kombinasi dengan kadar glukosa darah di Bpm"E" Kecamatan Purwosari Pasuruan. 1-6.

Soegondo, S., Sowondo, P., \& Subekti, I. 2009. Penatalaksanaan Diabetes Melitus Terpadu. Jakarta: Fakultas Kedokteran Universitas Indonesia.

Sugiyono. 2014. Statistika Untuk Penelitian. Bandung: Alfabeta.

Sukarni, I., \& Purwaningsih, W. 2013. Buku Ajar Keperawatan Maternitas. Yogyakarta: Nuha Medikaa.

Suyanto. 2011. Metodologi dan Aplikasi Penelitian Keperawatan. Yogyakarta: Nuha Medika.

Tarwoto. 2012. Keperawatan Medikal Bedah Gangguan Sistem Endokrin. Jakarta: CV.Trans Info Media.

Yulaikah, R. H. 2017. Perbedaan Tekanan Darah dan Indeks Massa Tubuh pada Akseptor Suntik Kombinasi dan Suntik Depomedroxprogesterone Asetat (DMPA). Jurnal Kebidanan Dan Kesehatan Tradisional, Volume 2, No $1,20$. 